\title{
An Investigation into the Consumers' Sensitivity of the Logistics Efficiency
}

\author{
Karim Garrouch \\ Higher Institute of Management, University of Sousse, Tunisia \\ Teaching assistant and member of the Research Unit MaPReCoB \\ 08 Rue de Kairouan, 5010, Ouardanine, Tunisia \\ Tel: +216-2453-9506_E-mail: karimg_2001@yahoo.fr \\ Mohamed Nabil Mzoughi (Corresponding author) \\ Higher Institute of Management, University of Sousse, Tunisia \\ Professor and director of the Research Unit MaPReCoB \\ BP 37, Khézama-Est, 4051, Sousse, Tunisia \\ Tel: +216-7333-2976_E-mail: teachershello@yahoo.fr \\ Ichrak Ben Slimane \\ Higher Institute of Management, University of Sousse, Tunisia \\ Member of the Research Unit MaPReCoB \\ 07 Avenue Ali Ibn Abi Taleb, 2074, Tunis, Tunisia \\ Tel: +216-9870-1950Ｅ-mail: ichrakbs@yahoo.fr \\ Olfa Bouhlel \\ Higher Institute of Management, University of Sousse, Tunisia \\ Teaching assistant and member of the Research Unit MaPReCoB \\ 79 Rue Tahar Sfar, 4070, M'saken, Sousse, Tunisia \\ Tel: +216-2229-1370Ｅ-mail: olfabouhlel2002@yahoo.fr
}

Received: January 4, 2011 Accepted: April 4, $2011 \quad$ doi:10.5430/ijba.v2n2p114

\begin{abstract}
This research's objective is to verify the relationships between the consumer's perception of logistics' efficiency, satisfaction and behavioral intention. The logistic components perceived by the consumer were identified by a qualitative research. A questionnaire was conducted nearby 290 participants in order to check the impact of loyalty and mood on the sensitivity to the logistic function's efficiency and the influence of the latter on satisfaction and the patronage intention. Results show that the sensitivity to logistics efficiency is found to be three dimensional. It is subdivided into sensitivity to merchandising, availability of products and associated information, logistical sensitivity at the department level and logistical sensitivity at the tills level. This research found that loyal consumers are less sensitive to logistics efficiency. The latter is positively influenced by shopper's mood. Satisfaction and patronage intention are influenced only by the logistical efficiency at the tills level.

This research can help the stores' managers to avoid problems triggered by the perception of logistical activities and to minimize their negative impacts by manipulating other in store variables. Its originality stems from the newness of considering the perception of the store's logistical function as a consumer variable which may have an impact on his behavior.
\end{abstract}

Keywords: Logistics sensitivity, Mood, Loyalty, Patronage intention, Satisfaction 


\section{Introduction}

Two types of products are supplied by retailers. The explicit ones are the tangible goods and implicit ones are the associated services (Keh and Teo, 2001). The latter integrates the logistic component as well as the situational factors (Grace and O'Cass, 2004).

Logistics guarantees a competitive advantage to the firm. It is synonymous of speed of delivery, reliability, reactivity and cheaper distribution (Morash et al., 1996; Zacharia and Mentzer, 2004). Its integration in the company's global strategy creates services and value to consumers (Williams et al., 1997; Zacharia and Mentzer, 2004).

"Logistics is no longer considered a routine, merely operational activity but a strategic variable which is a deciding factor in achieving customer satisfaction.” (Saura et al., 2010)

Due to the pressure of competitive strategies, the logistic function is under a deep transformation, leading to the redefinition of its role, mission and fields of action. Logistics cover the value's creation chain from the products conception until the final consumer (Jawab and Bouami, 2004). For instance, researchers and managers are interested in supply chain or global logistical chain, integrating customers, suppliers, providers, subcontractors... Moreover, logistics management becomes linked to the CRM and is considered as a source of competitive advantages.

One of store performance's criteria is to display products on the best conditions (Filser et al., 2001). Retailers include in their offers other variables such as the choice extent, services, quality, and particularly the logistical service quality (Lichtlé et al., 2000). Globally, an efficient logistics performance of the company contributes to the consumer's experience convenience, availability of the product, delivery, returns policy, etc (Ramanathan, 2010). A logistical problem can generate some negative effects on the retailer's performance. A product lacking in the store shelves may, for example, cause a drop of the firm image (Rulence, 2003).

Therefore, the consumer sensitivity to several elements of the logistical function may be a reason for the development or the deterioration of his relationship with the retailer. More specifically, it could explain many components of the consumer behaviour such as emotion, satisfaction, patronage intention... Some of those links has not been studied so far (Aurifeille and Quester, 2000; Bonnin et al., 2000; Lichtlé et al., 2000).

Actually, logistics has been mostly investigated according to a Business to Business logic or internal working procedure frameworks.

The novelty of this research stems from considering that the sensitivity to logistics is a factor which can explain the consumer behavior in a retailing context. The rationale behind this work is that the consumers can positively or negatively perceive some aspects of the logistical operations such as storage, shelves loading, cleaning... This perception may be well appreciated or be a source of irritation which induces different degrees of satisfaction-dissatisfaction. The intensity of the sensitivity to logistics may be influenced by the mood and by the loyalty previous to the visit where the consumer perceives logistical problems or performances. Actually the consumer can neglect or even forgive some logistical mistakes when he is already loyal or when he enters the store with a good mood.

The main research question is to what extent the consumer's sensitivity to the logistics efficiency contributes to his satisfaction and his behavioral intention?

\section{Conceptual Framework}

The logistics is defined as the set of tasks aiming to set up, to the least cost, products at the right time and place (Akbari Jokar et al., 2000). It is an activity chain related to the acquirement, movement, storage and delivery of goods (Ratliff and Nulty, 1997). "Logistics is a customer service, product-support utility that affects the profit of the company, and the cost to and satisfaction of the product user" (Brimer, 1995). It encompasses a complex set of activities which require a collection of metrics to adequately measure performance (Caplice and Sheffi, 1995). It includes functions of transport, distribution, bonding and storage. It is linked to production and marketing's functions and it is seen as a necessary activity to bring production and consumption into contact (Saura et al., 2010).

The logistics integrates, in addition to the physical tasks, market forecasting, services offered to customers and the location's choice of factories and warehouses (Akbari Jokar et al., 2000). It is a group of functions related to the flow of goods, information and payment between suppliers and customers, since the acquirement of raw materials until the recycling of finished products.

\subsection{Definition of logistics sensitivity}

Product can not insure alone the customer's satisfaction. It must be accompanied by secondary services in order to constitute a global offer (Lichtlé et al., 2000). The link between experiential marketing and performance has been 
partially approached in some works. It ignores, for instance, the relation with the store's Back-Office, especially the logistics and the purchase (Dupuis and Le Jean-Savreux, 2004). A control of the logistical factors allows a best management of the storage, contributing thus to an improvement of the purchase comfort and to the consumer's satisfaction.

The logistics sensitivity is defined as the individual's perception of the logistical performance, or lack of performance, valued before the purchase (Lichtlé et al., 2000). It is a purchaser's psychological characteristic expressing of the logistical service quality. The perception of logistical performance is not only the direct result of the last visit in the store, but also the indirect consequence of the previous visits. It is the perception of congruency between the logistical performance's indicators and the consumer's expectations. Measuring this variable comes to value the perception of different concerned operations. The efficient logistics is unperceived by consumers (Lichtlé et al., 2000, Aurifeille and Questers, 2000), but it can reduce purchase's brakes, waiting time, product lacking, etc. (Aurifeille and Quester, 2000; Lichtlé et al., 2000, 2001). Therefore, it is necessary to identify the logistical criteria perceived by consumer and conditions of existence of this perception in order to test their effect on the consumer's satisfaction or dissatisfaction and his behaviour.

The goal of logistics is to insure the continuity and fluidity of goods' flow (Hake and Paché, 1988; Dornier, 1997; Lichtlé et al., 2000). Concerning largely diffused products, consumer's expectations about logistics are: time and reliability of the delivery, product availability and information about the product circulation and its traceability (Dornier, 1997). The last criterion is especially important because of problems due to the origin of some foodstuffs (Lichtle et al., 2000). The consumer can react negatively if he (she) encounters problems at the purchase time: too close consumption's deadlines, product lacking in the store shells, etc. Consequently, the consumer could delay his purchase, buy another brand or go to another store (Fady and Séret, 1980). His reaction depends on the brand's notoriety as well as his loyalty to the brand and to the retailer.

The consumer can be sensitive to phenomena underlying the logistical performance. The latter can be a stores' differentiation means by proposing a home delivery service, providing information on sale's place, treating complaints and reducing the waiting time.

These factors of performance or lack of performance and their importance in the decision process are studied only in a global way in the literature, which is still modest around this topic. Therefore, a qualitative survey of exploratory nature is necessary.

\subsection{Antecedents and consequences of logistical sensitivity}

\subsubsection{Loyalty to the retailer}

The loyalty, often treated as a one-dimensional construct representing a behavioural component, is generally measured by observing the purchase sequence. For example, it may be measured by determining the percentage of brand's purchase in the sequence of the product acquisitions (Cunningham, 1956). The observation of several consecutive purchases of the brand can be considered as well (Tucker, 1964).

The idea that a faithful consumer buys regularly from the same supplier is criticized because of the insufficiency of the behavioral measure (Jacoby and Kyner, 1973). The re-purchase must be intentional and have to continue in the future (Oliver, 1997).

The notion of commitment constitutes the main difference between the true and the false loyalty. These two acceptances of the concept can be considered as the two extreme ranges of a consumer's commitment scale. In a relational approach, the loyalty is a commitment, deeply expressed by the consumer, to buy again a preferred product, in a coherent way in the future (Oliver, 1997). It includes four sequential elements:

- The cognitive loyalty: some beliefs generate the preference for a given brand (Harris and Goode, 2004),

- The emotional loyalty: a favorable feeling is based on a satisfactory use (Harris and Goode, 2004),

- The conative loyalty: it is the development of behavioral intentions characterized by a deep level of involvement (Harris and Goode, 2004),

- The loyalty of action: related to the conversion of intentions into actions, with the desire to overcome difficulties (Harris and Goode, 2004).

Traditionally, researchers consider that logistics plays an important role in maintaining customer loyalty (Ramanathan, 2010; Saura et al, 2010; Agatz et al., 2008). This vision stems from the idea that consumer experiences the logistics factors after making payments (Ramanathan, 2010). 
In this research, we seek to check the effect of the loyalty resulting from previous visits on the logistical sensitivity. Its measure means estimating the visit frequency in the setting of action's fidelity. A faithful customer uses less information to take his purchase decision. In this case, the behaviour will be based on weaker evaluation's criteria (Lichtlé et al., 2000). The consumer might less perceive the retailer's logistical performance because it will be difficult to compare it with other distributors.

\section{H1: The loyalty to the retailer influences negatively the shopper's sensitivity to the logistical function's efficiency.}

\subsubsection{Previous states of the individual}

The components of psychological state existing before the visit are considered as situational factors (Belks, 1974; Lutzes and Kakkars, 1975; Lichtlé et al., 2000; Lemoine and Plichon, 2000; Lemoine, 2001).The latters are, for example, individual's expectations, anxiety, stimulation and mood (Daucé and Rieunier, 2002). Some researchers recommend not appealing to this variable because of the confusion that it generates between the individual's features and situational cues (Wicker, 1975; Lemoine, 2001). It is also presented as an initial character of the individual which moderate the sensory stimuli effect on the behaviour (Rieunier, 1998, 2000).

Concerning the purchase situation, Lichtlé et al. (2000) evoke the informational environment and the internal environment of the store. The logistical sensitivity is especially influenced by the former. The customer's expectations before purchase are influenced by received information. The consumer expects indeed that some services are proposed with the product (Nagel and Cilliers, 1990; Lichtlé et al., 2000): respect of the delivery time, availability of products, after sale service, etc.

The shopper will be more sensitive to a logistical performance lack if expectations are not confirmed (Parasuraman et al., 1985).

The mood is one of the components of the individual's previous states. It is the consumer's emotional state at the time of the exhibition to stimuli (MacKenzie and Lutz, 1989). People have generally more positive attitude when their mood is better (Lichtlé et al., 2000). Assessments are rather negative if one is in a bad mood (Isen et al., 1978; Isen and Shalker, 1982). Consumers can be more sensitive to a logistical problem if their mood is unfavorable. They will notice more easily a lack of goods or a close consumption's deadline (Lichtlé et al., 2000).

\section{H2: Mood has a positive influence on the shopper's sensitivity to the logistical function's efficiency.}

\subsubsection{Satisfaction}

This concept is central in relational marketing researches (Yi, 1990; Oliver, 1997). In a post-purchase perspective, Oliver (1981) defines it as "a psychological state resulting from a comparison between the expectation about the product and the feelings resulting from the purchase and the consumption's experience" (Ben Issa and N'Goala, 2004). The satisfaction can either be analyzed in an individual level, that of the consumer, or an aggregate level, that of the firm, the industry, or the retailer. It can rise from a specific or lasting relation with a product, a brand, an industry (Ben Issa and N'Goala, 2004) or a retailer. It is a results' evaluation of a consumption experience based on a set of goals or standards, translating an achievement, an under achievement or an over achievement (Oliver, 1997).

The impact of the logistics on the consumer's satisfaction has been ignored by the consumer behavior literature analyses (Lichtlé et al., 2001, 2002). Treated simultaneously with several situational factors, it proves to be a source of satisfaction if it is effective, and reciprocally.

The overall endeavour of logistics function is to reach high customer satisfaction (Renko and Ficko, 2010). The provision of the distributor's service aims to facilitate the purchase through the goods presentation, providing information about the products, offering of a suitable packaging, setting up of delivery's options and adequate payment, etc. (Grace and O'Cass, , 2004). Many logistical function elements may have an impact on consumer satisfaction. Lichtlé et al. (2001) show that of the inherent data to the logistics such as the product's accessibility, the easy access to the store or the deadline of consumption has an effect on the satisfaction.

H3: The sensitivity of the shopper to the efficiency of logistical function has a positive impact on global satisfaction.

2.2.4 Impact of the sensitivity to the logistical function's efficiency on the Patronage intention

Retailers' main interest is to produce more via preserving loyal patronage (Keng et al, 2007).

The link between the logistics and the consumer's behavior has been verified (Aurifeille and Quester, 2000; Bonnin et al., 2000; Lichtlé et al., 2002). The logistical sensitivity may have a positive effect on the intention to come back if it corresponds to a positive assessment. This impact is negative if the consumer notes a weak output. For example a product lacking in the store shelves may generate a drop of the firm image (Rulence, 2003). Frustrated, some customers can be brought to frequent other stores (Jallais et al., 1994). 
H4: The sensitivity to the logistical function's efficiency has a positive effect on the patronage intention.

\section{Research Methodology}

A quantitative study, involving the administration of a survey, was conducted in order to validate empirically the identified antecedents and consequences of the logistical function efficiency. The survey instrument consisted of five variables and 31 items which were identified through a comprehensive review of the logistics and policy distribution literature. Prior to empirical testing, the instrument was refined through an expert panel of marketing academics and researchers. The instrument was divided into two sections. The first one represented a group of items measuring the concepts. The second one corresponded to the identification sheet.

This study was conducted in two steps. A pilot study was conducted to refine the test instrument. 32 respondents were interviewed in this pilot testing phase with all surveys being included in the exploratory analysis. The second step involved the administration, via face-to- face interviews, of the survey instrument nearby consumers getting out of different stores and accepting to collaborate. Respondents were asked to give their perception of the logistical function efficiency on a five point Likert scale ranging from 1, indicating very poor, to 5, indicating very good. 290 useable surveys were collected and 114 were rejected, which gave a response rate of 71.78 per cent. This high proportion was due to the face to face approach used in this research. The surveys also encompassed logistical function efficiency evaluations from different stores. The interviews were conducted in four cities in Tunisia: Sousse, Tunis, Mahdia, Kairouan.

\subsection{Measures}

\subsubsection{The sensitivity of the logistical function}

A qualitative procedure has been applied in order to generate an exhaustive set of logistical elements perceived by the consumer. Four experts visited several stores and noted positive and negative elements of logistics that can be perceived by shoppers. A selection of other elements was identified in previous frameworks (Lichtlé et al., 2001, 2002). Three experts have been asked to eliminate items that not belong to the logistics. The retained items list is the following:

1. All products and all brands that you had foreseen to buy were available.

2. The deadline of product consumption in which you were interested was appropriate.

3. All products were available.

4. Packing bags provided by the cashier were available.

5. All the departments appeared well supplied.

6. There was a big choice of products.

7. The displayed prices were identical to those typed in the tills.

8. The store (ground, departments, tills...) was clean.

9. Information about different product features was sufficient.

10. The departments' disposition seemed to be logical.

11. At the time of complaints that you formulated, the problem treatment was satisfying

12. The after-sales service is well assured.

13. Some products are stocked in areas which are not foreseen for that purpose.

14. The store was supplied during the visit.

15. Some departments were supplied during the visit.

16. You noted a stock shortage.

17. The number of tills was sufficient.

18. There were closed tills.

19. The number of trolleys was sufficient.

20. The store assures a delivery service.

Items $3,4,6,7,8,9,10,11,12,17,18$ and 19 are related to the strategic choices of the distributor concerning the assortment, the merchandising and the customer service. It shows the difficulty for the consumer to isolate the logistics in relation to other managerial variables. 
3.1.2 Antecedents and consequences of the sensitivity to the logistical function's efficiency

Considering the fact that the data collection had to take place during the customer's visit in the store, the questionnaire had to be short in order to maximize the number of interviewees.

The patronage intention was measured by Dodds, Monroe and Grewal (1991)'s scale composed of the following items:

- The likelihood that I would shop in this store is very high.

- $\quad$ I would be willing to buy merchandise at this store.

- I would be willing to recommend this store to my friends.

The validity of this scale is verified in many works (Grewal et al, 2003, Baker et al, 2002; Cronin et al, 2000)

The satisfaction has been approached holistically through only one item indicating if the consumer is globally satisfied by the store.

Peterson and Sauber's one-dimensional scale of 4 items (in Mattila, 1999) was used to measure the consumer's mood. After scale's adaptation, two items have been preserved:

Item 1: I cross a period of good mood.

Item 2: During the visit to the store, I was in a good mood.

The loyalty has been measured by the consumer's rate of frequentation before the last visit. The reason of this choice is that the loyalty is considered in this work as an antecedent of the sensitivity to logistics. This effect stems from the idea that the sensitivity may be less intense when the consumer is used to see logistics advantages or problems in the frequented store.

The interviewee must choose one of the following propositions:

- $\quad$ Several times a week

- $\quad$ Once a week

- $\quad$ Once per two weeks

- $\quad$ Once a month

- $\quad$ Less than once a month

\subsection{Data collection}

290 consumers getting out of different stores in Tunisia: Champion, Carrefour, Promogro, Magasin Général, Monoprix have been invited to fill the research questionnaire. The sample was composed of 149 men, 131 women. 10 respondents did not indicate their gender. The survey started on September 17 and ended on 21 December 2008. It has been done during all days of the week. The selected stores were supermarkets with food predominance regarding their modern logistical systems, (Hake and Paché, 1988). The investigation nearby consumers in situation of real purchase aims to improve the external validity of the research. Demographic characteristics of the sample, including gender, education, visit, visit's day and income, are summarized in Table 1.

\section{Results and discussions}

The data was entered into SPSS 17.0 and checked for incorrect entries and missing data. A Principal Component Analysis (PCA) was also conducted on each of the measurement scales (Sensitivity to the logistic function, Mood, Loyalty, patronage intention, satisfaction). The data were then transferred to AMOS 18 to perform the remainder of the statistical analysis required. The Confirmatory Factor Analysis (CFA) was used to refine and validate the measurement scales. CFA is the "appropriate statistical test particularly as the researchers had a reasonably sound knowledge of the number of factors that were required to explain the intercorrelations among the measurement variables" (Sureshchandar et al., 2002). To statistically confirm the proposed model of the sensitivity to the logistical function's efficiency, the "CFA approach is the most appropriate method" (Sureshchandar et al. 2002). The proposed model is based on logic, prior empirical research and theoretical results.

\subsection{Scale Refinement, Reliability and Validity}

Unidimensionality should be evaluated initially, before examining reliability and validity (Hair et al., 1995). Principal Component Analysis was applied first, for each of the factors. Then Confirmatory Factor Analysis was conducted. We notice the absence of CFA for measuring instruments consisted of three items only (Ayadi, 2007; Galan, 2003; Korchia, 2001) and it for "reasons of statistical identification: the model is just said identified" (Bollen, on 1989 in Korchia, on 
2001). Reliability and validity are essential to standardize the measurement scales and to show whether they really measure what they are thought to measure (Al-Hawari, Hartley and Ward, 2005). To test reliability, squared multiple correlations (greater than 0.5 (Holmes-Smith 2001 in Al-Hawari, Hartley and Ward, 2005), Byrne 2001)) for each measurement item, composite reliability, and variance extracted for each factor are used.

The validity of measurements was verified by using CFA. Items of which tests were not significant and of which values were lower to 2 were deleted (Anderson and Gerbing, 1988).

The structural equation modeling by the method of maximum of likelihood were implemented although data do not perfectly fill the conditions of normality. Indeed, the reports Kurtosis / Standard error and Skewness / Standard errors are not lower to 2 for observed data. This can be due to the sample's features, "yes sayers" people have a tendency to opt for the extreme answers (Lacaze, 1998).

- According to the PCA, items of the variable sensitivity of the logistical function's efficiency were summarized by three factors which Eigen values were superior to one $(4.569,1.26$ and 1.075). $49.316 \%$ of the initial information was preserved (table2).

The CFA showed that items 9,11,6,1 and 10 reflect the factor "the merchandising sensitivity, availability of products and associated information". Items 14, 15 and 19 correspond to the factor "logistical sensitivity at the level of shelves". Finally, items 4 and 7 describe the factor "sensitivity to logistical efficiency at the level of the tills". In this measurement model, the variance extracted and the R2 were greater than 0.5 , which indicated a good reliability level (Holmes-Smith 2001 in Al-Hawari, Hartley and Ward, 2005; Hair et al. 1995). Composite reliability (0.81) was calculated, using Fornell and Larker's (1981) formula, to measure the reliability (Al-Hawari, Hartley and Ward, 2005). It should be greater than 0.7 (Holmes-Smith 2001 in Al-Hawari, Hartley and Ward, 2005; Hair et al. 1995).

- $\quad$ The three items of the store patronage intention were summarized by one factor of which Eigen value is 2.218 and that represents $73.94 \%$ of the initial information (table 3).

- The two items of the variable mood had high correlations with the only resulting factor of the PCA. The latter had an Eigen value of 1.643 and describes $82.133 \%$ of the total variance (table 4 ).

\subsection{Model verification}

After conducting the validity and reliability tests for all of the factors of the sensitivity to the logistical function's efficiency, it is also necessary to demonstrate the overall fit of the measurement model. It was determined by confirmatory factor analysis (CFA).

To evaluate the measurement model in this research it was necessary to use a variety of "goodness of fit" indices (Byrne, 2001). Accordingly, the assessment of the model fit was based on multiple criteria (Roussel and al., 2002; Hair and al., 1998): the normed Khi-Square, the Root Mean Square Error of Approximation (RMSEA, $<0.05$ according to Steiger and Lind, $1980 ;<0.08$ according to Browne and Cudeck, 1989), the Root Mean Square Residual (RMSR, closest to zero according to Jöreskog and Sörbom, 1984), the Goodness of Fit Index (GFI, > 0.9 Jöreskog and Sörbom according to $1984 ;>0.95$ according to Bollen and Long 1993), the Adjusted Goodness of Fit Index (AGFI, > Jöreskog and Sörbom according to $1984 ;>0.95$ according to Bollen and Long 1993), the Normed Fit Index (NFI, $>0.9$ according to Bentler and Bonett, 1980), the Nonnormed Fit Index (NNFI, > 0.95 according to Bentler et Bonett, $1980 \&$ Tucker et Lewis, 1973).

The retained structural model had a significant Khi-Square $(\mathrm{p}=0.000)$. The value of $\mathrm{X} 2 / \mathrm{ddl}$ was less than 2 . The GFI and AGFI values were respectively 0.929 and 0.897 , which confirms the quality of the model. The NFI of 0.846 and NNFI of 0.890 were acceptable as well. The RMSR was equal to 0.05 . The RMSEA, equal to 0.043 , was lower that the limit of 0.05 and 0.08 . Therefore, the model was parsimonious (table 5).

Table 5 shows the acceptable fit criteria and the sensitivity to the logistical function's efficiency fit indices values. All of the statistical values of the final measurement model indicated that the model fitted well in representing the data.

The mood influences positively the sensitivity to the logistical function's efficiency, the Beta's value was 0.33 for the sensitivity to the merchandising, availability of products and associated information, 0,277 for sensitivity to logistical function's efficiency in shelves and 0,309 for the sensitivity to logistics in the tills level. All relations were positive and significant, the hypothesis $\mathrm{H} 2$ was confirmed.

The loyalty had a significant impact on the three dimensions of the sensitivity to the logistical function's efficiency. The negative sign of Bêta showed that relations between variables considered in the first hypothesis were all negative. Therefore, H1 was confirmed. 
The sensitivity to the logistical function's efficiency of tills is the only dimension that influences the satisfaction and patronage intention. $\mathrm{H} 3$ and $\mathrm{H} 4$ were partially confirmed.

The Structural Equation Model is showed in figure1.

\section{Conclusion}

This research explains the way in which consumer considers the logistical function's efficiency in the decision process. Antecedents of the logistical sensitivity have been highlighted, since the literature did not practically approach this topic. It is probably related to the difficulty to know if the logistics influences the consumer's decision.

The logistical sensitivity is multi-dimensional. It integrates the sensitivity to the merchandising, to the availability of products and associated information, the shelves logistics sensitivity and the sensitivity to tills logistics. These dimensions are influenced by the loyalty to the retailer and the consumer's mood.

The sensitivity to logistics at the department level has a significant effect on the consumer satisfaction. He may perceive some signs of the logistics function at the departments of the store like supplying the department with merchandise. The latter is considered as a performance because it gives an idea about the fact that the merchandise will be always available. Moreover it can be an indicator of the regularity and reliability of the store management.

The sensitivity to logistics at the tills' level has an effect on the patronage intention. It is the last impression about the store. It is a dimension that could be related to the waiting time at the tills. Actually it concerns the availability of the packing bags. When they are not available, the consumer will have to wait until the cashier brings them.

The logistical Sensitivity at the tills level includes the fact that the displayed prices are the real ones. It is important because it strengthens the trust toward the store when the consumer is sure that he is not misled.

As a managerial implication, the managers have to be sure that the merchandises are available. Supplying the shelves or the store during the visit does not bother the consumer so it is allowed to do that.

Another managerial implication: the availability of packing bags is very important to maintain the frequentation intention of the consumer. The cashiers have to make sure they have enough bags and to communicate with managers every time they notice that there are lacking bags to serve the next consumer.

A third implication: mistakes concerning the displayed prices could happen. The store must plan how to treat complaints about such a problem. Apologies, reductions, gifts... are proposed as ways to recover, but the better way is to form managers to avoid such inaccuracy

The search for a logistical performance, constantly increasing, can constitute a real competitive advantage for retailers. It does not only mean that retailers have to reach an acceptable level of efficiency of this function, but also to avoid its deficiencies.

The mood, having a positive effect on the logistical sensitivity to the tills' logistics, can be manipulated. Atmosphere factors may influence the emotional states of visitors. The negative impact of an unfavorable perception of the logistics can be minimized and the positive effects of the sensitivity to this function's efficiency can be strengthened.

This investigation used a comprehensive procedure to identify some antecedents and consequences of the sensitivity to logistical efficiency. Unfortunately, it did not use Churchill's (1979) or Rossiter's (2002) procedure to measure the logistical sensitivity. The latter did not show the negative and positive aspects of logistics' perception. Future researches can test the impact of logistics breakdowns more precisely, or even the irritation that they can trigger. The critical incident method may be a better way to highlight such a subject.

Intention of patronage is considered as a part of shopper's behavioral intentions. The use of the latter concept and scale would have further enriched the results of this research.

The satisfaction is measured by one item. Using a full scale to measure this concept may be a way to have better estimators for the conceptual model.

The interaction between loyalty and the sensitivity to logistics is studied promptly. Actually, it is assumed that loyalty is an antecedent to sensitivity and not a consequence. More over the loyalty is measured here as the previous rate of frequentation.

Future works may avoid such a limit by using scales measuring the loyalty before and after the occurrence of perceptible logistical problems or performances.

It will be interesting to investigate in-store reactions to logistical problems. For instance, the identification of substitution phenomena between products within the assortment is worth studying. 


\section{References}

Agatz, N.A.H. Fleischmann, M.Van Nunen, J.A.E.E., (2008), E-fulfillment and multi-channel distribution - a review, European Journal of Operational Research, (187), 339-356. doi:10.1016/j.ejor.2007.04.024, http://dx.doi.org/10.1016/j.ejor.2007.04.024

Akbari Jokar, M., Frein, F. \& Dupont, L. (2000), Sur l'évolution du concept de logistique, Les Troisièmes Rencontres Internationales de la Recherche en Logistique Trois-Rivières, 9, 10 et 11 mai 2000.

Al-Hawari M., Hartley N. \& Ward T. (2005), Measuring Banks' Automated Service Quality: A Confirmatory Factor Analysis Approach, Marketing Bulletin, 1-19.

Anderson, J.C. \& Gerbing, D.W. (1988), Structural Equation Modeling in Practice: A Review and Recommended two-Step Approach, Psychological Bulletin, Vol 103, Mai, pp. 411-423, doi:10.1037/0033-2909.103.3.41, http://dx.doi.org/10.1037/0033-2909.103.3.411

Aptel, O. (2000), Le rôle de la logistique dans la connaissance du niveau des stocks: Le cas du secteur hospitalier, Les Troisièmes Rencontres Internationales de la Recherche en Logistique, Trois-Rivières, 9, 10 et 11 mai 2000.

Aurifeille, J.R \& Quester, P.G. (2000), Globalisation ou internationalisation : une méthode d'analyse fondée sur les profils d'implication, faire de la recherche en logistique et distribution ? Edition N.Fabbe-Costes, J.Colin \& G. Paché, Paris, Vuibert FNEGE, 231-249.

Aurifeille, J-R \& Pinto, M.P. (2000), Segmentation de la demande en fonction de sa sensibilité aux dates de péremption : concepts et illustration empirique fondée sur les classes latentes. Les Troisièmes Rencontres Internationales de la Recherche en Logistique, Trois-Rivières, 9, 10 et 11 mai 2000.

Ayadi N. (2007), Les déterminants et les chemins de la décision du consommateur en situation risquée, Thèse pour l'obtention du titre de Docteur en Sciences de Gestion, Université des sciences sociales de Toulouse, Institut d'Administration des Entreprises.

Baker, J. Parasuraman, A. Grewal, D. \& Voss, G.B. (2002). The Influence of Multiple Store Environment Cues on Perceived Merchandise Value and Patronage Intentions, Journal of Marketing, (66), 120-141. doi:10.1509/jmkg.66.2.120.18470, http://dx.doi.org/10.1509/jmkg.66.2.120.18470

Belk, R.W. (1974). An Exploratory Assessment of Situational Effects in Buyer Behavior, Journal of Marketing Research, (11), 156-163. doi:10.2307/3150553, http://dx.doi.org/10.2307/3150553

Ben Issa, H. \& N'Goala, G. (2004). Les effets de la satisfaction économique et de la satisfaction sociale sur les réponses à l'insatisfaction ponctuelle : le rôle modérateur de l'implication et de l'expertise subjective du consommateur, Actes du XXème congrès AFM, 6 et 7 May, St Malo.

Bentler P. M. \& Bonett D. G. (1980), Significance tests and goodness of fit in the analysis of covariance structures, Psychological Bulletin, (88), 588-606. doi:10.1037/0033-2909.88.3.588, http://dx.doi.org/10.1037/0033-2909.88.3.588

Bollen K. (1989), Structural equations with latent variables, New York : John Wiley \& sons in Korchia M. (2001), Connaissances des marques stockées en mémoire par les consommateurs : Modèle théorique et test empirique, Thèse pour l'obtention du titre de Docteur en Sciences de Gestion, Université de droit, d'économie et des sciences d'Aix-Marseille III.

Bollen K. A. \& Long J. S. (1993), Testing structural equation models, Newsbury Park (CA), Sage Publications.

Bonnin, G., Drugeon-Lichtlé, M.C. \& Plichon, V. (2000), La logistique de distribution face aux nouveaux comportements du consommateur, Faire de la recherche en logistique et distribution? Edition N. Fabbe-Costes, J. Colin \&G. Paché, Paris, Vuibert FNEGE, 249-260.

Brimer, R.C. (1995), A consideration of the components essential to an integrated logistics support network, Logistics Information Management, (8), 8-11. doi:10.1108/09576059510091850, http://dx.doi.org/10.1108/09576059510091850

Browne M. W. \& Cudeck R. (1989), Single sample cross validation indices for covariance structures, Multivariate Behavioral Research, 24, 445-455, doi:10.1207/s15327906mbr2404_4, http://dx.doi.org/10.1207/s15327906mbr2404_4

Byrne B. (2001). Structural equation modelling with AMOS. New Jersey. 
Caplice, C. \&Sheffi, Y. (1995), A Review and Evaluation of Logistics Performance Measurement Systems, The International Journal of Logistics Management, 6, 61- 74, doi:10.1108/09574099510805279, http://dx.doi.org/10.1108/09574099510805279

Churchill, Jr.G. A,(1979). A paradigm for developing better measures of marketing constructs, Journal of marketing, (16), 64-73.

Colin, J. \& Paché, G. (1988), La logistique de distribution, Paris, Chotard Associés éditeurs.

Cronin, J. J.., Brady, M. K.. Hult, \& T.M, (2000), Assessing the effects of quality, value, and customer satisfaction on consumer behavioral intentions in service environments, Journal of Retailing, (76), 193-218, doi:10.1016/S0022-4359(00)00028-2, http://dx.doi.org/10.1016/S0022-4359(00)00028-2

Cunningham, R.M., (1956), Brand Loyalty: What, Where, How Much? Havard Business Review, (34), 116-128, doi: 10.1177/135676679900500105, http://dx.doi.org/10.1177/135676679900500105

Daucé, B. \& Rieunier, S. (2002). Le marketing sensoriel du point de vente, Recherche et Applications en Marketing, (17), 45-65.

Dornier, P.P. (1997), Logistique, in Simon, Y. \& Joffre, P., (éds), Encyclopédie de Gestion.

Dupuis, M., \& Le Jean-savreux, D. (2004), Marketing expérientiel et performance des enseignes de distribution, Revue Française du Marketing (198),89-97.

Englewood Cliffs: Prentice-Hall International in Al-Hawari M., Hartley N. \& Ward T. (2005), Measuring Banks Automated Service Quality: A Confirmatory Factor Analysis Approach, Marketing Bulletin, (16), Article 1.

Fady, A. \& Séret, M. (1980). Merchandising, Paris, Vuibert Gestion.

Filser, M. (2004), La stratégie de la distribution : Des interrogations managériales aux contributions académiques, Revue Française du Marketing, (198), 7-17.

Filser, M., Des Garets, Y. \& Paché, G. (2001), La distribution: organisation et stratégie, Editions EMS.

Fornell C. \& Larker D. (1981). Evaluating structural equation models with unobserved variables and Measurement errors, Journal of Research Marketing, (27), 445-466.

Galan J.P. (2003), Musique et réponses à la publicité : effets des caractéristiques, de la préférence et de la congruence musicales, Thèse pour l'obtention du titre de Docteur en Sciences de Gestion, Université des sciences sociales de Toulouse, Institut d'Administration des Entreprises.

Grace, D. \& O'Cass, A. (2005), An Examination of the Antecedents of Repatronage Intentions across Different Retail Store Formats, Journal of retailing and Consumer Services, (12), 227-243, doi: 10.1016/j.jretconser.2004.08.001, http://dx.doi.org/10.1016/j.jretconser.2004.08.001

Grewal, D. Baker, J. Levy, M. \& Voss G.B, (2003). The effects of wait expectations and store atmosphere evaluations on patronage intentions in service-intensive retail stores,

Journal of Retailing, (79), 259-268, doi:10.1016/j.jretai.2003.09.006, http://dx.doi.org/10.1016/j.jretai.2003.09.006

Hair J., Anderson R.,Tatham R. \& Black W. (1995). Multivariate Data Analysis with Readings.

Harris, L.C. \& Goode, M.M.H. (2004), The Four Levels of Loyalty and the Pivotal Role of Trust: A Study of Online Service Dynamics, Journal of Retailing, (80), 139-158, doi:10.1016/j.jretai.2004.04.002, http://dx.doi.org/10.1016/j.jretai.2004.04.002

Holmes-Smith P. (2001). Introduction to Structural Equation Modelling using LISREAL. Perth: ACSPRI-Winter training Program in Al-Hawari M., Hartley N. \&Ward T. (2005), Measuring Banks' Automated Service Quality: A Confirmatory Factor Analysis Approach, Marketing Bulletin, (16), Article 1.

Isen, A.M. \& Shalker, T.E. (1982), The Effect of Feeling State on Evaluation of Positive, Neutral and Negative Stimuli: When You «Accentuate the Positive », do you «Eliminate the Negative? Social Psychology Quarterly, (45), 58-63. doi:10.2307/3033676, http://dx.doi.org/10.2307/3033676

Isen, A.M. Clark, M. Shalker, T.E. \& Karp, L. (1978), Affect, Accessibility of Material in Memory and Behavior: A Cognitive Loop?, Journal of Personality and social Psychology, (36), 1-12, doi :10.1037/0022-3514.36.1.1, http://dx.doi.org/10.1037/0022-3514.36.1.1

Jacoby, J. \& Kyner, D.B. (1973), Brand Loyalty versus Repeat Purchasing Behavior, Journal of Marketing Research, (10), 1-9. doi:10.2307/3149402, http://dx.doi.org/10.2307/3149402 
Jallais, J. Orsoni, J. \& Fady, A. (1994), Le marketing dans le commerce de détail, Paris, Vuibert.

Jawab, F. \& Bouami, D. (2004), La démarche Supply Chain Management enjeux et stratégies : Cas du commerce électronique et de la grande distribution, Revue des Sciences de Gestion : Direction et Gestion., (39), 95-110.

Jöreskog K.G. \& Sörbom D. (1984), LISREL VI user's guide, $3^{\text {rd }}$ edition, Mooresville, IN: Scientific Software.

Keh, H.T. \& Teo, C.W. (2001), Retail Customers as Partial Employees in Service Provision a Conceptual Framework, International Journal of Retail and Distribution Management, (29), 370-378, doi: 10.1108/09590550110396944, http://dx.doi.org/10.1108/09590550110396944

Keng, C-J. Huang T-L. Zheng, L-J. \& Hsu, M.K. (2007), Modeling service encounters and customer experiential value in retailing An empirical investigation of shopping mall customers in Taiwan, International, Journal of Service Industry Management, (18), 349-367, doi:10.1108/09564230710778137, http://dx.doi.org/10.1108/09564230710778137

Korchia M. (2001), Connaissances des marques stockées en mémoire par les consommateurs : Modèle théorique et test empirique, Thèse pour l'obtention du titre de Docteur en Sciences de Gestion, Université de droit, d'économie et des sciences d'Aix-Marseille III.

Lacaze, A. (1998), La socialisation du personnel en contact avec la clientèle dans les services, W.P N 517, Mars, CEROG.

Lemoine, J.F. \& Plichon, V. (2000), Le rôle des facteurs situationnels dans l'explication des réactions affectives du consommateur à l'intérieur d'un point de vente, Actes du Congrès de l'Association Française du Marketing, Montréal, Mai.

Lemoine, J.F. (2001), Comment tenir compte des émotions du consommateur, Revue Française de Gestion, (134), 47-60.

Lichtlé, M.C, Llosa S. \& Plichon, V. (2002), La contribution des différents éléments d'une grande surface alimentaire à la satisfaction du client, Recherche et Applications en Marketing, (17).

Lichtlé, M.C, Manzano, M. \& Plichon, V. (2000), La sensibilité du consommateur à la logistique: Mise en évidence des variables déterminantes, Les Troisièmes Rencontres Internationales de la Recherche en Logistique, Trois-Rivières, 9 , 10 et 11 mai 2000.

Lichtlé, M.C, Plichon, V. \& Llosa, S. (2001), La contribution des différents éléments d'une grande surface alimentaire à la satisfaction du client : l'influence des critères logistiques, des facteurs d'atmosphères et des services, actes du 17ème congrès de L'AFM.

Lutz, R. \& Kakkar, P. (1975): The Psychological Situation as a Determinant of Consumer Behavior, Advances in Consumer Research, (2), 439-453.

MacKenzie, S.B. \& Lutz, R.J. (1989), An empirical Examination of the Structural Antecedents of Attitude toward the Ad in an Advertising Pre-Testing Context, Journal of Marketing, April, (53), 48-65.

Mattila, A.S. (1999), The Role of Culture and Purchase Motivation in Service Encounter Evaluations, Journal of Services Marketing, (13), 367-389.

Morash, E. A. Cornelia D, \& Shawnee, V. (1996), Strategic Logistics Capabilities for Competitive Advantages and Firm Success, Journal of Business Logistics, (17), 1-22 in Zacharia, Z.G \& Mentzer, J.T., (2004), Logistics Salience in a Changing Environment, Journal of Business Logistics, (25), 187-211.

Nagel, J.A \& Cilliers, W. (1990), Customer Satisfaction: A Comprehensive Approach. International Journal of Physical Distribution and Logistics Management, (20), 1-46.

Oliver, R.L. (1981), Measurement and Evaluation of Satisfaction Process in Retail Setting. Journal of Retailing, (57), Autumn, 25-48.

Oliver, R.L. (1997), Satisfaction: A Behavioral Perspective on the Consumer. New York: McGraw-Hill.

Oliver, R.L. (1999). Whence Customer Loyalty, Journal of Marketing, (63), 33-44. doi:10.2307/1252099, http://dx.doi.org/10.2307/1252099

Parasuraman, A., Zeithaml, V.A. \& Berry, L.L. (1985), A Conceptual Model of Service Quality and its Implications for Future Research. Journal of Marketing, (49), 41-50. doi:10.2307/1251430, http://dx.doi.org/10.2307/1251430

Perrien, J., Chéron, E. \& Zins, M. (1983), Recherche en Marketing: Méthodes et décisions, Gaëtan Morin.

Pons, J. Chevalier, P. (1996), La logistique intégrée, HERMES, 34-35. 
Ramanathan, R. (2010), The moderating roles of risk and efficiency on the relationship between logistics performance and customer loyalty in e-commerce, Transportation Research, (46) , 950-962. doi:10.1016/j.jretconser.2010.03.012, http://dx.doi.org/10.1016/j.jretconser.2010.03.012

Ratliff, H.D. \& Nulty, W.G. (1997), Logistics Composite Modeling, in Artiba, A. and Elmaghraby, S.E. The Planning and Scheduling of Production Systems, Methodologies and Applications, Chapman \& Hall, 10-53.

Renko, S. Ficko, D, (2010), New logistics technologies in improving customer value in retailing service, Journal of Retailing and Consumer Services, (17), 216-223

Rieunier, S. (1998), L'influence de la musique d'ambiance sur le comportement du client : Revue de la littérature, défis méthodologiques et voies de recherches, Recherche et Applications en Marketing, (13), 57-76.

Rieunier, S. (2000), L'influence de la musique d'ambiance sur le comportement des consommateurs sur le lieu de vente, Thèse de Sciences de Gestion, Université Paris IX, Paris.

Ritzer, G. (1999), Enchanting a Disenchanted World. Revolutionizing the Means of Consumption, Pine Forge Press, Thousand Oaks, Ca.

Rossiter, J.R., (2002), The C-OAR-SE procedure for scale development in marketing, International Journal of Research in Marketing, (19), 305-335. doi:10.1016/S0167-8116(02)00097-6, http://dx.doi.org/10.1016/S0167-8116(02)00097-6

Roussel, P. Durrieu, F. Campoy, E. \& El Akremi, A. (2002), Méthode d'équations structurelles : Recherche et Applications en Gestion, Edition Economica.

Rulence, D. (2003), Gestion des réseaux de points de vente: L'importance de la dimension spatiale, Recherche et Applications en Marketing, (18), 65-81.

Saura I. Francés G.S. Fuentes-Blasco, M., (2010), Antecedents and consequences of logistics value: And empirical investigation in the Spanish market, Industrial Marketing Management, (39), 493-506. doi:10.1016/j.indmarman.2008.11.007, http://dx.doi.org/10.1016/j.indmarman.2008.11.007

Steiger J. H. \& Lind J.C. (1980), Statistically based tests for the number of common factors, Annual Congress of the Psychometric Society, May, Iowa City, IO.

Sureshchandar G., Rajendran C. \& Anantharaman R. (2002), Determinants of customer perceived service quality: A confirmatory factor analysis approach. Journal of Service Marketing, (16), 9-34. doi:10.1108/08876040210419398, http://dx.doi.org/10.1108/08876040210419398

Tixier, D. \& Mate, H. (1991), La logistique, PUF.

Tucker L. R. \& Lewis C. (1973), The reliability coefficient for maximum likelihood factor analysis, Psychometrica, (38), $1-10$.

Tucker, W.T. (1964), The Development of Brand Loyalty, Journal of Marketing Research, (1).

Wicker, A.W. (1975): Commentaries on Belk' Situational Variables and Consumer Behavior, Journal of Consumer Research, (2), 165-167.

Williams, L. Avril, N. Dimples, I. \&Terrence, F. (1997), Logistics Integration: The Effect of Information Technology, Team Composition and Corporate Competitive Positioning, Journal of Business Logistics, (18), 31-41.

Yi, Y. (1990), A Critical Review of Consumer Satisfaction, Review of Marketing, 68-123.

Zacharia, Z.G., \& Mentzer, J.T. (2004), Logistics Salience in a Changing Environment, Journal of Business Logistics, (25), 187-211.

\section{Notes}

Note1. Tunisian Dinar

Note2. Arrows in dotted lines on the model described by the figure above corresponds to the not significant relations. 
Table 1. Respondents profile

\begin{tabular}{|c|c|c|c|}
\hline \multicolumn{2}{|r|}{ Characteristics } & Frequency & $\%$ \\
\hline \multirow{3}{*}{ Gender } & Female & 131 & 45.2 \\
\hline & Male & 149 & 51.4 \\
\hline & Missing & 10 & 3.4 \\
\hline \multirow{3}{*}{ Visit } & Unaccompanied & 115 & 39.7 \\
\hline & Accompanied & 172 & 59.3 \\
\hline & Missing & 3 & 1 \\
\hline \multirow{8}{*}{ Visit's day } & 1 Monday & 24 & 8.3 \\
\hline & 2 Tuesday & 62 & 21.4 \\
\hline & 3 Wednesday & 28 & 9.7 \\
\hline & 4 Thursday & 18 & 6.2 \\
\hline & 5 Friday & 17 & 5.9 \\
\hline & 6 Saturday & 28 & 9.7 \\
\hline & 7 Sunday & 79 & 27.2 \\
\hline & Missing & 34 & 11.7 \\
\hline \multirow{9}{*}{ Education } & Primary school & 1 & 0.3 \\
\hline & Secondary school & 42 & 14.5 \\
\hline & University : High school diploma +2 & 44 & 15.2 \\
\hline & University : High school diploma +3 & 58 & 20.0 \\
\hline & University : High school diploma +4 & 87 & 30.0 \\
\hline & University : High school diploma +5 & 22 & 7.6 \\
\hline & University : High school diploma +6 & 22 & 7.6 \\
\hline & Plus & 13 & 4.5 \\
\hline & Missing & 1 & 0.3 \\
\hline \multirow{7}{*}{ Income } & $\mathrm{x}<200$ DT $($ note 1$)$ & 115 & 39.7 \\
\hline & $200 \mathrm{DT} \leq \mathrm{x} \quad<500 \mathrm{DT}$ & 79 & 27.2 \\
\hline & $500 \mathrm{DT} \leq \mathrm{x}<1000 \mathrm{DT}$ & 61 & 21.0 \\
\hline & $1000 \mathrm{DT} \leq \mathrm{x}<1500 \mathrm{DT}$ & 18 & 6.2 \\
\hline & $\geq 1500 \mathrm{DT}$ & 8 & 2.8 \\
\hline & Missing & 9 & 3.1 \\
\hline & Total & 290 & 100 \\
\hline
\end{tabular}


Table 2. PCA's result of the sensitivity of the logistical function's efficiency

\begin{tabular}{|c|c|c|c|c|}
\hline \multirow[b]{2}{*}{ Items } & \multicolumn{4}{|c|}{ Loadings } \\
\hline & $\begin{array}{l}\text { Merchandising } \\
\text { sensitivity, } \\
\text { availability of } \\
\text { products and } \\
\text { associated } \\
\text { information }\end{array}$ & $\begin{array}{c}\text { Logistical } \\
\text { sensitivity at the } \\
\text { level of shelves }\end{array}$ & \multicolumn{2}{|c|}{$\begin{array}{l}\text { Sensitivity to logistical } \\
\text { efficiency at the level of } \\
\text { the tills }\end{array}$} \\
\hline Item 9 & 0.720 & & & \\
\hline Item 11 & 0.702 & & & \\
\hline Item 6 & 0.616 & & & \\
\hline Item 1 & 0.560 & & & \\
\hline Item 10 & 0.533 & & & \\
\hline Item 14 & & 0.704 & & \\
\hline Item 15 & & 0.770 & & \\
\hline Item 19 & & 0.696 & & \\
\hline Item 4 & & & & \\
\hline Item 7 & & & & \\
\hline KMO & & 0.812 & & \\
\hline Test de Bartlett & & $531.808 ; \mathrm{p}=0$ & & \\
\hline Eigen value & 4.569 & & 1.26 & 1.075 \\
\hline $\begin{array}{c}\text { Total variance } \\
\text { explained }\end{array}$ & & $49.316 \%$ & & \\
\hline Cronbach's Alpha & 0.661 & & 0.649 & - \\
\hline
\end{tabular}

Table 3. PCA's result of the store patronage

\begin{tabular}{|c|c|c|}
\hline \multicolumn{1}{|c|}{ Items } & Communalities & Loadings \\
\hline Item $1:$ Intention to come back & 0.775 & 0.880 \\
\hline Item $2:$ Purchase intention & 0.775 & 0.880 \\
\hline Item 3 : Intention of recommendation & 0.668 & 0.817 \\
\hline KMO & \multicolumn{2}{|c|}{0.704} \\
\hline Test de Bartlett & \multicolumn{2}{|c|}{$220.965 ; \mathrm{p}=0.000$} \\
\hline Eigen value & \multicolumn{2}{|c|}{$73.940 \%$} \\
\hline Total variance explained & \multicolumn{2}{|c|}{0.818} \\
\hline Cronbach's Alpha &
\end{tabular}

Table 4. PCA's result of the mood

\begin{tabular}{|c|c|c|}
\hline \multicolumn{1}{|c|}{ Items } & Communalities & Loadings \\
\hline Item 1 : I cross a period of good mood & 0.821 & 0.906 \\
\hline $\begin{array}{l}\text { Item 2 : During the visit to the store, I was in } \\
\text { a good mood }\end{array}$ & 0.821 & 0.906 \\
\hline KMO & \multicolumn{2}{|c|}{0.500} \\
\hline Test de Bartlett & $147.836 ; \mathrm{p}=0.000$ \\
\hline Eigen value & \multicolumn{2}{|c|}{1.643} \\
\hline Total variance explained & $82.133 \%$ \\
\hline Cronbach's Alpha & - \\
\hline
\end{tabular}


Table 5. Goodness of fit indices for the sensitivity to the logistical function's efficiency model

\begin{tabular}{|c|c|}
\hline GFI & 0.929 \\
\hline AGFI & 0.897 \\
\hline RMSR & 0.05 \\
\hline RMSEA & 0.043 \\
\hline CMIN/DF & Less than 2 \\
\hline NFI & 0.846 \\
\hline NNFI = TLI & 0.890 \\
\hline
\end{tabular}

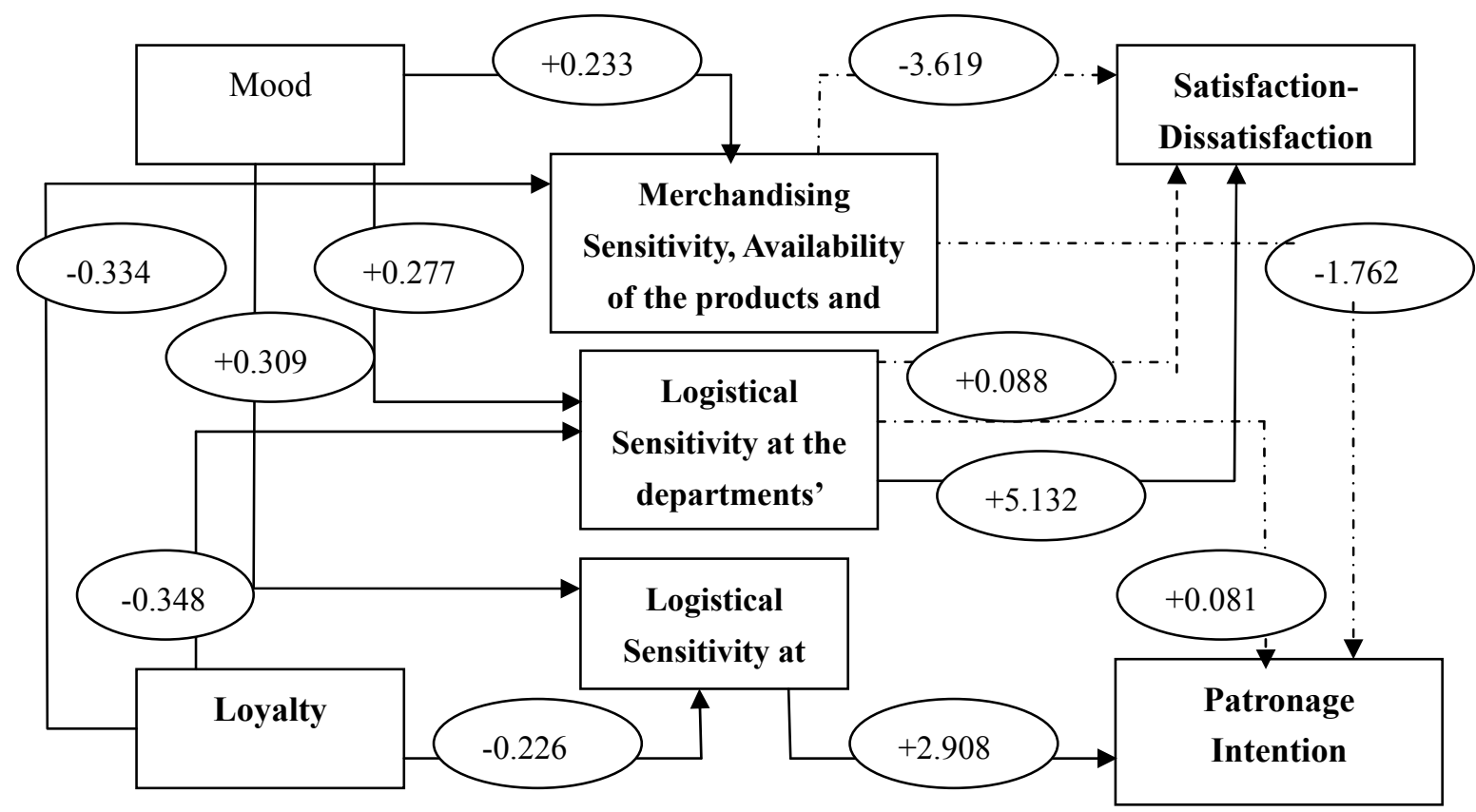

Figure 1. Sensitivity to the logistical function's efficiency Structural Equation Model (note2) 